\title{
The Effect of International Trade on Food Security at Southeast Asian Countries
}

\author{
TRAN DINH LY \\ Nong Lam University \\ VIETNAM \\ PHAM XUAN DONG \\ HCMC University of Food Industry \\ VIETNAM \\ LE HOANG ANH \\ Institute for Research Science and Banking Technology \\ Banking University Ho Chi Minh City \\ VIETNAM \\ PHAM THI HA AN \\ Van Lang University \\ VIETNAM
}

\begin{abstract}
For decades, although the world has made significant progress in the fight against hunger, food insecurity has been considered as the top concern of countries, especially developing countries. In this study, we use panel data of 10 Southeast Asian countries for the period from 2000-2015 to evaluate the effect of international trade on food security. Applying panel data regression methods such as fixed effects model (FE), random effects model (RE), and feasible generalized least squares model (FGLS), the results show the positive mpact of international trade on food security on all three aspects of food availability, stability, and access at each country. Besides, other factors such as agricultural productivity, the share of agricultural land over the total land area, percentage of farmers in total population, and inflation also affect to food security of Southeast Asian countries on several aspects. Based on the results, we propose some policy implications for Southeast Asian countries to deal with food insecurity problems.
\end{abstract}

Key-words: - International trade; Food security; Fixed effects model (FE); Random effects model (RE); Feasible generalized least squares model (FGLS)

Received: August 5, 2019. Revised: February 18, 2020. Accepted: February 29, 2020. Published: March 10, 2020.

\section{Introduction}

Over the past decades, although the world agriculture sector has made considerable progress, food insecurity continues in many countries. According to FAO (2012), the world still has over 800 million people suffering from malnutrition and pressure on the population issues, and poverty reduction continues to be a significant challenge globally.

Food insecurity and malnutrition have a direct impact on the health and development of people generally in the field of learning, individual productivity, and economic development (World Bank, 2006; Upton et al., 2016). Therefore, FAO (2014) emphasized the necessity of putting food security issues at the highest level in national policy formulation and international research programs.
Countries should effort to create an enabling environment for improving food security by enhancing domestic production capacity and promoting international trade.

Many developed and developing countries have made significant policy reforms over the past three decades, including trade policy reform aiming to reduce taxes and non-tax barriers. Trade policy reforms have contributed to the growth of international trade in the world (Anderson, 2010). Trade reforms are expected to help boost economic growth, reduce poverty, and improve the food availability for consumption in countries (FAO, 2003; Dorosh et al., 2016; Alesandro et al., 2017; Taraba, 2019; Okunlola et al., 2020).

Much empirical research has focused on the effects of globalization and trade liberalization on 
aspects of economic development, such as economic growth and poverty. To the poverty aspect, the researches focus on the impact of globalization and trade liberalization on food insecurity (Traub and Jayne, 2008). However, these studies have been limited to qualitative analysis of the effects of international trade on food security.

Explicitly, at the global level, international trade can link production with consumption of food and can play an essential role in ensuring food security. International trade allows global production activities to take place in the most appropriate areas and food to move from countries with an abundant food source to countries that do not have enough supplies (Runge et al., 2003). At the national level, the openness growth of a nation on trade can lead to an increase in the total amount of food availability for the population in that country and create more food, contributing to increasing food security.

Thus, the impact of international trade on food security, both empirical research and policy, has received little attention (Guha Khasnobis et al., 2007; World Bank, 2006). In this study, we give a more specific view and focus on the overall level of food security of the national population indicated through three aspects of food availability, accessibility, and stability. This approach allows the author to seriously assess the impact of international trade openness and other factors on all aspects of food security.

The next section - section 2 - presents theoretical basics about the impact of national trade on food security. Section 3 explains the research methodology and data description. Section 4 presents the empirical results of the study. Finally, section 5 proposes some policy implications from the research results.

\section{Theoretical basics}

\subsection{The concept of food security}

According to FAO (1996), food security is a state in which all people, at all time, have both physical and economic access with an adequate, safe, and nutritious food source, meeting the diet and food tastes, ensuring an active and healthy life. This definition emphasizes the multidimensional properties of food security, including availability, stability, and accessibility. The availability of food means that sufficient food is provided to meet consumer demand. The stability refers to the issue of ensuring the food supply in time of severe food shortage. The accessibility refers to ensure that everybody has the opportunity to access the basic food he needs. (FAO, 2003).

\subsection{The effect of international trade on food security}

The impact of international trade on food security is explained through aspects of food security, including availability, stability, and accessibility.

Specifically:

For the issue of ensuring food availability, the world market has a function as an essential food supply for the needs of the countries, especially for countries where domestic food production is restricted by agricultural climate factors and other factors (Runge et al., 2003).

Through international trade, countries can import food cheaper than domestically produced food. This is especially useful for countries with production and trade distorted by greater trade liberalization, helping reduce the price distortion and bring special treatment to market participants. International trade will then lead to an increase in the total amount of food availability for the national population and provide a variety of goods (FAO, 2000).

Besides, through international trade, export revenues of the countries can be used to import input products, such as machinery, fertilizers, and pesticides. This, in turn, helps to improve domestic food production.

For the issues of food supply stability, international trade can help resolve shortages as well as excess food in the domestic market. Hence, this will stabilize the national food supply and reduce food price fluctuation. A more liberal trade mechanism may reduce the change of food supply because the countries have many ways to improve food availability compared to the case of a selfsufficient policy.

Besides, international trade to food products will help the exporting countries have a rich source of foreign currency, which can help stabilize the domestic food supply. On the other hand, through international trade, some countries can export their dominant food and use foreign currency obtained to import food from other countries (FAO, 2003). This activity also helps produce food and foodstuffs taken place in the most appropriate areas.

Finally, international trade affects food accessibility through price efficiency, the availability of production factors, economic growth, household income, and employment. 
International trade helps the market participants to access food sources at a more affordable price. For example, many farmers could sell a part of surplus food in the domestic market or export to buy other food. Besides, the number of food they can obtain is affected by trade policies because these policies affect the price of food in the market. The more open trade policy is, the more goods that farmers, producers can export at a country. Also, they may indirectly benefit from the increasing demand for their products due to a rising number of participants from other countries on trade liberalization (Winters et al., 2004; Alesandro et al., 2017; Asrol, 2019). Moreover, trade openness promotes the export of domestically produced food will create more job opportunities and enhance labor income (Muhammad Aswar Limi, 2018).

This process can play an important role in reducing poverty and improving food security (Jaffe et al., 2011). Finally, the trade openness of a nation can positively affect the ability to receive food aid (FAO, 2003). The study of Alesina and Dollar (2000) showed that the developed countries, especially the Nordic countries, give a lot of aid for countries with trade openness policy and good state institutional conditions.

\section{Methodology}

\subsection{Research model}

The impact of international trade on food security at Southeast Asian countries shows through the model proposed by Jan Dithmer, Awudu Abdulai (2017), as follows:

$$
\begin{gathered}
F S_{i t}=\beta_{0}+\beta_{1} \times T O_{i t}+\beta_{2} \times G D P C_{i t}+\beta_{3} \times \\
A P R O_{i t}+\beta_{4} \times R U R A L P_{i t}+\beta_{5} \times A R L A_{i t}+\beta_{6} \times \\
P O P G_{i t}+\beta_{7} \times I N F_{i t}+\varepsilon_{t}
\end{gathered}
$$$$
\text { Where: }
$$

- $\mathrm{FS}_{\mathrm{it}}$ is the dependent variable representing food security and measured based on 03 aspects of availability, stability, and accessibility at country $i$ year $t$.

- $\mathrm{TO}_{\text {it }}$ is international trade, measured as the ratio of the total of import and export values to GDP of country i year $t$.

- ARLA $_{\text {it }}$ represents the share of agriculture land over the total land area of country i year $t$.

- $\mathrm{POPG}_{\text {it }}$ represents the population growth of country i year $t$.
- RURALP ${ }_{i t}$ represents the percentage of farmers in the total population of country i year t.

- $\mathrm{APRO}_{\mathrm{ii}}$ represents the agricultural productivity of country $i$ year $t$.

- INF is the inflation of country i year $t$.

\subsection{Estimated methods}

Model (1) is estimated by the method, as follows:

$$
y_{i t}=B_{1}+B_{2} X_{i t}+a Z_{i t}+u_{i t}
$$

Where: $Z$ denotes individual-specific characteristics (here we consider the specifics of country i). Depending on the effect of individual specifics $Z_{i}$ to model, different panel data models will be formed.

- To the effects that can be observed and calculated, we use the fixed-effects model.

- In contrast, to the effects that can be not calculated and random, we use the random-effects model.

\subsubsection{Fixed effects model (FEM)}

In model (1), each subject has its specifics that can affect to explainable variables. The fixed-effects model analyzes the relationship between the residuals of each subject to explainable variables that control and isolate the effects of individual specifics (time-invariant estimators).

This method can get net effects estimators of explainable variables on the dependent variable. The estimated model is given by:

$$
Y_{i t}=C_{i}+B X_{i t}+u_{i t}
$$

Where: $Y_{i t}$ is dependent variable with $i$ is the $i-$ th country, and $t$ is the $t$-th year. $X_{i t}$ is explainable variables, $C_{i}$ is the intercept of each observed subject, B is coefficients, $U_{i t}$ is residuals.

The above model adds index $\mathrm{i}$ for intercept $\mathrm{C}$ to distinguish the intercepts of different countries. This difference may come from the distinct characteristics of each country, or differences in management policies, operations of each country.

\subsubsection{Random Effects Model}

The difference between the random-effects model and the fixed-effects model is shown in the variation between subjects. If the variation between subjects is correlated to the independent variables in the fixed-effects model, the variation between subjects is random and not correlated to the independent variables in the random-effects model.

Therefore, if the variation between subjects is correlated to the independent variables, REM is more suitable than FEM where the residual of each 
subject (not correlated to the independent variables) is considered a new explainable variable.

The basic idea of the random effects model also starts from the model:

$$
Y_{i t}=C_{i}+B X_{i t}+u_{i t}
$$

Where: $C_{i}$ is constant in FEM, but in REM, it is assumed a random variable with the average of $\mathrm{C}$ and the intercept value is described as follows:

$$
C_{i}=C+\varepsilon_{i} \text { given }(\mathrm{i}=1,2,3 \ldots \mathrm{n})
$$

Where: $\varepsilon_{\text {it }}$ is a random error term with an average of 0 and unchanged variance

Replace to the model, and we have: $Y_{i t}=C+B X_{i t}+u_{i t}+\varepsilon_{i}$

or: $Y_{i t}=C+B X_{i t}+w_{i t}$ with $w_{i t}=\varepsilon_{i}+u_{i t}$

Where: $\varepsilon_{\mathrm{i}}$ is the error term of each individual (specifics of each country). $\mu_{\mathrm{it}}$ is the error item of a combination of each individual of each country by time.

In general, the random-effects model or fixed facts model is better for the research depends on the assumption that if there is a correlation of $\varepsilon_{\mathrm{i}}$ and explainable variable $\mathrm{X}$. If it is assumed that there is no correlation, fixed facts model should be more consistent and vice versa. Hausman test is one of methods to choose between random effects or fixed effects.

\subsubsection{Comparison between random effects and fixed effects}

Using Hausman's test:

$$
\begin{aligned}
& \mathrm{H}_{0}: \operatorname{Cov}\left(X_{1} i t, u_{1} i\right)=0 \text { (random effects) } \\
& \mathrm{H}_{1}: \operatorname{Cov}\left(X_{1} i t, u_{1} i\right) \neq 0 \text { (fixed effects) } \\
& -\quad \text { If } \mathrm{p} \text {-value }<\alpha \text {, reject the null } \\
& \text { hypothesis } \mathrm{H}_{0} . \\
& -\quad \text { If } \mathrm{p} \text {-value }>\alpha \text {, accept the null } \\
& \text { hypothesis } \mathrm{H}_{0} .
\end{aligned}
$$

\subsubsection{Necessary tests}

Wald test is used to test variance change (homoscedastic) across subjects.

$\mathrm{H}_{0}$ : variance across subjects is constant with $\mathrm{p}$ value $>0.05$, the null hypothesis $\mathrm{H}_{0}$ is accepted.

Wooldridge test is used to test autocorrelation in panel data.

$\mathrm{H}_{0}$ : There is no autocorrelation. With p-value > 0.05 , the null hypothesis $\mathrm{H}_{0}$ is accepted.

If the chosen model appears autocorrelation or homoscedastic phenomenon across subjects, we shall use the Feasible General Least Square model (FGLS) to fix this phenomenon.

\subsection{Data}

The research is conducted at Southeast Asian covering 11 countries. However, the data of food security, which is collected from the database of the Food and Agriculture Organization (FAO) for the period from 2000-2015, excluding Singapore. Therefore, the study is conducted with a sample consisting of 10 Southeast Asian countries for the period 2000-2015.

Data used in the model is collected from reliable sources such as World Economic Outlook (WEO), International Monetary Fund (IMF), and World Development Indicators (WDI) of the World Bank. Other necessary qualitative information about Southeast Asian countries of the study is also collected from the Food and Agriculture Organization (FAO). The research data is the balance panel.

\section{Empirical results}

The effect of international trade on food security on the aspect of food availability is shown in the model with the dependent variable, $\mathrm{FS}_{\text {it }}$ that is measured as average dietary energy supply adequacy - ADESA. The estimated results are presented in Table 1 as follows:

Table 1. The estimated result of models with dependent variable ADESA

\begin{tabular}{llll}
\hline & \multicolumn{3}{c}{ Dependent variable: ADESA } \\
\cline { 2 - 4 } & $(1)$ & $(2)$ & $(3)$ \\
\hline \multirow{2}{*}{ TO } & $0,0739701^{* * *}$ & $0,0577706^{* * *}$ & $0,0164377^{* *}$ \\
& $(5,50)$ & $(4,52)$ & $(2,32)$ \\
GDPC & 0,0535294 & 0,0465451 & 0,0095348 \\
& $(1,49)$ & $(1,27)$ & $(1,13)$ \\
APRO & $0,0073489 * * *$ & $0,0052262^{* * *}$ & $0,0014876^{* * *}$ \\
& $(7,92)$ & $(6,93)$ & $(3,81)$ \\
RURALP & $-0,1702775$ & $-0,5016238^{* * *}$ & $-0,6023728^{* * *}$ \\
ARLA & $(-1,59)$ & $(-7,50)$ & $(-14,26)$ \\
& $1,506865^{* * *}$ & 0,2893661 & $0,3366688^{* * *}$ \\
& $(3,23)$ & $(1,63)$ & $(4,17)$
\end{tabular}




\begin{tabular}{llll} 
POPG & $1,826433^{* *}$ & $1,843918^{* *}$ & $2,148974 * * *$ \\
& $(2,05)$ & $(2,04)$ & $(5,97)$ \\
INF & $-0,0850156^{* *}$ & $-0,1069543^{* *}$ & 0,0139385 \\
& $(-2,09)$ & $(-2,53)$ & $(0,79)$ \\
\multirow{2}{*}{ CONS } & $66,12034 * * *$ & $110,9245^{* * *}$ & $130,8128^{* * *}$ \\
\hline Observations & $(5,46)$ & $(19,47)$ & $(44,90)$ \\
\hline \multirow{2}{*}{ Hausman test } & 160 & 160 & 160 \\
\hline \multirow{2}{*}{ Modified Wald test } & $\chi^{2}(7)=55,13$ & \\
& $\mathrm{p}$-value $=0,0000$ & & \\
\hline \multirow{2}{*}{ Wooldridge test } & $\chi^{2}(10)=194,28$ & \\
& $\mathrm{p}$-value $=0,0000$ & & \\
& $\mathrm{~F}(1,9)=185,686$ & & \\
\hline
\end{tabular}

The estimated results of models determine effects of international trade to food security through food availability aspect with the fixed-effects model - model (1), the random-effects model - model (2), and the Feasible Generalized Least Squares Model (FGLS) - model (3). The dependent variable ADESA represents food availability in the models. Hausman, Modified Wald, and Wooldridge tests are presented by p-value. Numbers in parentheses below the coefficients are the $t$ statistics.

$* * *$ Significant level at $1 \%$

**Significant level at $5 \%$

*Significant level at 10\%

The estimated results of the fixed-effects model and the random-effects model are quite similar.

Specifically, in the fixed-effects model, the regression coefficients of TO, APRO, ARLA variables significant level at $1 \%$, and the regression coefficients of POPG, INF variables significant level at $5 \%$.

With the random-effects model, the regression coefficients of TO, APRO, ARLA variables are significant at $1 \%$, and the regression coefficients of POPG, INF variables are significant at 5\%.

Hausman's test results with p-value less than $5 \%$ indicate that the fixed-effects model is more consistent.

However, Modified Wald and Wooldridge tests show that the models exist homoscedastic and autocorrelation phenomenon. To fix this phenomenon, the research uses the feasible generalized least squares model. The estimated results of the model show the regression coefficients of APRO, RURALP, ARLA, POPG variables are significant at $1 \%$ and the regression coefficients of TO variables are significant at $5 \%$.
Source: calculated from Stata 16.0 software Thus, international trade has an effect on food security on the aspect of food availability of countries. Specifically, as international trade increases by $1 \%$, the average dietary energy supply adequacy will increase by $0.02 \%$. Beyond variable international trade, the results also show the positive effects of agricultural productivity on food security. At the same time, the population increase also puts pressure on increasing the average dietary energy supply adequacy.

These results are consistent with the findings of Jan Dithmer, Awudu Abdulai (2017). Besides, the rise of the inflation rate will negatively influence food security issues of Southeast Asian countries due to an increase in input costs of the agricultural sectors.

The effect of international trade on food security on the aspect of food accessibility is shown in the model with the dependent variable; $\mathrm{FS}_{\mathrm{it}}$ is measured by the Prevalence of undernourishment (POU). The estimated result is presented in Table 2 as follows:

Table 2: The estimated result of models with dependent variable POU

\begin{tabular}{llll}
\hline & \multicolumn{3}{c}{ Dependent variable: POU } \\
\cline { 2 - 4 } & $(1)$ & $(2)$ & $(3)$ \\
\hline \multirow{2}{*}{ TO } & $-0,0695713^{* * *}$ & $-0,0512041^{* * *}$ & $-0,025156^{* * *}$ \\
GDPC & $(-4,96)$ & $(-3,79)$ & $(-3,86)$ \\
& $-0,0152062$ & $-0,0258719$ & $-0,0083239$
\end{tabular}




\begin{tabular}{llll} 
& $(-0,41)$ & $(-0,67)$ & $(-0,60)$ \\
APRO & $-0,0057507 * * *$ & $-0,0044812 * * *$ & $-0,0016549 * * *$ \\
& $(-5,94)$ & $(-5,50)$ & $(-5,64)$ \\
RURALP & $0,2659559 * *$ & $0,5985659 * * *$ & $0,6044959^{* * *}$ \\
\multirow{2}{*}{ ARLA } & $(2,38)$ & $(8,20)$ & $(21,69)$ \\
& $-2,395415 * * *$ & $-0,5763312 * * *$ & $-0,379321^{* * *}$ \\
POPG & $(-4,92)$ & $(-2,88)$ & $(-7,01)$ \\
& $-0,6895164$ & $-0,97171$ & $-1,536944 * * *$ \\
INF & $(-0,74)$ & $(-1,02)$ & $(-2,83)$ \\
\multirow{2}{*}{ CONS } & $0,1117181^{* * *}$ & $0,1442393 * * *$ & 0,0048277 \\
& $(2,63)$ & $(3,27)$ & $(0,799)$ \\
Observations & $60,3172 * * *$ & 10,04717 & $-3,035388^{*}$ \\
\multirow{2}{*}{ Hausman test } & $(4,77)$ & $(1,58)$ & $(-1,69)$ \\
\hline \multirow{2}{*}{ Modified Wald test } & 160 & 160 & 160 \\
\hline \multirow{2}{*}{ Wooldridge test } & $\chi^{2}(7)=21,68$ & & \\
\hline
\end{tabular}

The estimated results of models determine effects of international trade to food security through food accessibility aspect with the Fixed-effects models - model (1), the Random-effects model - model (2), and the Feasible generalized least squares model (FGLS) - model (3). The dependent variable POU represents food accessibility in the models. Hausman, Modified Wald, and Wooldridge tests are presented by p-value. Numbers in parentheses below the coefficients are the t statistics.

*** Significant level at 1\%

**Significant level at 5\%

*Significant level at $10 \%$

The estimated result of the fixed-effects model and the random-effects model is quite similar. Specifically, in the fixed-effects model, the regression coefficients of TO, APRO, ARLA, INF variables are significant at $1 \%$, and the regression coefficients of RURALP variables are significant at $5 \%$.

In the random-effects model, the regression coefficients of TO, APRO, ARLA, RAURALP, INF are variables significant at $1 \%$. Hausman test results with $\mathrm{p}$-value less than $5 \%$ indicate that the fixedeffects model is more suitable.

However, Modified Wald and Wooldridge tests show that the models exist homoscedastic and autocorrelation phenomenon. To fix this phenomenon, the research uses the feasible generalized least squares model. The estimated results of the model show the regression coefficients of TO, APRO, ARLA, RURALP, POPG variables are significant at $1 \%$.

Thus, international trade has an effect on food security in the aspect of countries' food
Source: calculated from Stata 16.0 software accessibility. Specifically, as international trade increases by $1 \%$, the prevalence of undernourishment will decrease by $0.03 \%$.

Beyond the international trade variable, the results still show that when agricultural productivity and agricultural land rate in the total land area increase, then the prevalence of the undernourishment of the country will decrease. The result also shows that if the percentage of farmers in the total population increases, the prevalence of undernourishment will increase. This can be explained by the fact that the quite low incomes coming from agricultural activity have affected to enable to access to food. These results are also consistent with the findings of Jan Dithmer, Awudu Abdlai (2017).

The effect of international trade on food security on the aspect of food accessibility is shown in the model with the dependent variable; $\mathrm{FS}_{\mathrm{it}}$ is measured by Per capita food supply variability - FSV. The estimated results are presented in Table 3 below: 
Table 3: The estimated result of models with dependent variable FSV

\begin{tabular}{|c|c|c|c|}
\hline & \multicolumn{3}{|c|}{ Dependent variable: FSV } \\
\hline & (1) & (2) & (3) \\
\hline TO & $\begin{array}{l}0,1182535^{*} \\
(1,84)\end{array}$ & $\begin{array}{l}0,1125002 * * \\
(2,30)\end{array}$ & $\begin{array}{l}0,1508968 * * * \\
(4,22)\end{array}$ \\
\hline GDPC & $\begin{array}{l}0,0156074 \\
(0,09)\end{array}$ & $\begin{array}{l}0,2874047^{*} \\
(1,66)\end{array}$ & $\begin{array}{l}-0,0137986 \\
(-0,08)\end{array}$ \\
\hline APRO & $\begin{array}{l}0,0331527 * * * \\
(-7,48)\end{array}$ & $\begin{array}{l}0,0146471 * * * \\
(-6,26)\end{array}$ & $\begin{array}{l}0,0064597 * * * \\
(-3,57)\end{array}$ \\
\hline RURALP & $\begin{array}{l}-0,0036111 \\
(-0,01)\end{array}$ & $\begin{array}{l}0,344711^{*} \\
(1,73)\end{array}$ & $\begin{array}{l}0,0770228 \\
(0,58)\end{array}$ \\
\hline ARLA & $\begin{array}{l}4,028804 * \\
(1,81)\end{array}$ & $\begin{array}{l}0,3603294 \\
(0,82)\end{array}$ & $\begin{array}{l}0,1821736 \\
(0,78)\end{array}$ \\
\hline POPG & $\begin{array}{l}-1,559752 \\
(-0,37)\end{array}$ & $\begin{array}{l}3,469082 \\
(0,86)\end{array}$ & $\begin{array}{l}0,5740641 \\
(0,15)\end{array}$ \\
\hline INF & $\begin{array}{l}-0,2854524 \\
(-1,47)\end{array}$ & $\begin{array}{l}-0,2719339 \\
(-1,34)\end{array}$ & $\begin{array}{l}-0,0438386 \\
(-0,44)\end{array}$ \\
\hline _CONS & $\begin{array}{l}79,5979 \\
(1,38)\end{array}$ & $\begin{array}{l}42,51385 * * * \\
(2,80)\end{array}$ & $\begin{array}{l}32,77427 * * * \\
(2,89)\end{array}$ \\
\hline Observations & 160 & 160 & 160 \\
\hline Hausman test & $\begin{array}{c}\chi^{2}(7)=35,45 \\
p \text {-value }=0,0000\end{array}$ & & \\
\hline Modified Wald test & $\begin{array}{l}\chi^{2}(10)=52,01 \\
\text { p-value }=0,0000\end{array}$ & & \\
\hline Wooldridge test & $\begin{array}{l}F(1,9)=105,468 \\
\text { p-value }=0,0000\end{array}$ & & \\
\hline
\end{tabular}

The estimated results of models determine effects of international trade to food security through food stability aspect with the fixed-effects models - model (1), the random-effects model - model (2), and the Feasible generalized least squares model (FGLS) - model (3). The dependent variable FSV represents food stability in the models. Hausman, Modified Wald, and Wooldridge tests are presented via p-value. Numbers in parentheses below the coefficients are the $t$ statistics.

*** Significant level at 1\%

**Significant level at 5\%

*Significant level at 10\%

The results show that in the fixed-effects model, the regression coefficients of APRO variable are significant at $1 \%$ and the regression coefficients of TO, ARLA variables are significant at $10 \%$. With the random-effects model, the regression coefficients of APRO variable are significant at $1 \%$, the regression coefficients of TO variable are significant at $5 \%$, and the regression coefficients of GDPC, RURALP variable are significant at $10 \%$. Hausman's test results with p-value less than $5 \%$ indicate that the fixed-effects model is more consistent.

However, Modified Wald and Wooldridge tests show that the models exist homoscedastic and autocorrelation phenomenon. To fix this phenomenon, the research uses the Feasible generalized least squares model. The estimated
Source: calculated from Stata 12.0 software results of the model show the regression coefficients of TO, APRO variables are significant at $1 \%$.

Therefore, international trade has an effect on food security on the aspect of countries' food stability. Specifically, as international trade increases, then it will lead to an increase in Per capita food supply variability. The results also show that when the rate of agricultural productivity increases, it will increase Per capita food supply.

\section{Conclusion and Policy Implications.}

\subsection{Conclusion}

The results show the positive impact of international trade on food security on all three aspects of food availability, stability and accessibility at each country. 
Besides, other factors such as agricultural productivity, the agricultural land share of total land area, the percentage of farmers in total population, and inflation also affect to food security of Southeast Asian countries on several aspects.

Based on the results, we propose some policy implication for Southeast Asian countries to deal with the food insecurity problems.

\subsection{Policy Implications}

Firstly, the results show the roles of expanding international trade to ensure the food security of countries. Therefore, the issues of expanding international trade should be considered in policies about food security in the countries. Expanding international trade could be performed through reducing trade barriers and protection of Government. However, policies to expand international trade should be seen as a supporting solution to help ensure food security. In addition, the countries need to combine the expanding international trade policies with other labor and social policies to ensure the domestic production sector not affected by the negative effects of trade liberalization. For example, in order to ensure farmers not affected by negative effects of North American Free Trade Agreement on prices of basic crops, the Mexican government has implemented the PROCAMPO remittance program to compensate farmers affected by price fluctuations of basic crops when they join in the agreement (winters and Davis, 2009).

Secondly, it is important to develop the economy and agriculture productivity in general to enhance food security. Thus it should require the policies of developing agriculture to help increase agricultural productivity and expand food production. Introducing new techniques, providing credit, extending services, and inputting materials must be the components of any national food security strategy. However, these strategies must be sustainable. To achieve these things, it is necessary to encourage sustainable agriculture development, combine the efforts to expand agriculture production to ensure food security with protecting nature resources (Marble and Fritschel, 2014).

Thirdly, the results also show that inflation has a negative impact on food security in the countries. The problem of political instability and the efficiency of public investments is the one of inflation causes. This result supports the requirements of international committees that prevent and reduce political complies that must be included in the food security policies (FAO, 2006). Moreover, the Governments should pay attention to the early warning system on food security to reduce the impacts of drought and other climate phenomena on food security for affected people. The investment should focus on finding new crop varieties adaptable to extreme climatic conditions.

\subsection{Future Research}

Future studies may apply the procedure carried out by this study for a larger sample size. Doing this will make the results more general. Besides, future studies can add other independent variables to the model to obtain new results. One variable that can be considered to add to the model is the development of Artificial Intelligence technology. In recent years, Artificial Intelligence technology has been particularly helpful in helping governments and organizations like the World Food Programme (WFP) address problems in agriculture by providing a more granular understanding of the impact of specific shocks on agriculture, in addition to predicting crop yields and future events. Therefore, future research may add variables related to artificial intelligence development to the model. This can help to consider more fully the aspects of food safety.

\section{References}

[1] Alesandro, O., Daniel, C., Swinnen, J., (2017). Trade Liberalization and Child Mortality: a Synthetic Control Method. Working Papers Department of Economics 567787, KU Leuven, Faculty of Business and Economics, Department of Economics.

[2] Anderson, K., (2010). Krueger/Schiff/Valdes revisited agricultural price and trade policy reform in developing countries since 1960. Policy Research Working Paper Series 5165, the World Bank.

[3] Asrol, H. (2019). Structures of Revenue, Expenditure, and Welfare of Household Farmers in Kampar Regency, Riau Indonesia. WSEAS Transactions on Business and Economics, 16, 1-8.

[4] Dithmer, J., Abdulai, A., (2017). Does trade openness contribute to food security? A dynamic panel analysis. Food Policy 69 (2017) 218-230.

[5] Dorosh, P.A., Rashid, S., van Asselt, J., (2016). Enhancing food security in South 
Sudan: the role of markets and regional trade. Agric. Econ. 47 (6), 697-707.

[6] FAO, (2003). Trade Reforms and Food Security: Conceptualizing the Linkages. $\underline{\text { FAO }}$, Rome.

[7] FAO, (2006). Trade Reforms and Food Security: Country Case Studies and Synthesis. FAO, Rome.

[8] FAO, (2012). The State of Food Insecurity in the World 2012. FAO, Rome.

[9] FAO, (2014). The State of Food Insecurity in the World 2014. FAO, Rome

[10] Guha-Khasnobis, B., Acharya, S.S., Davis, B., (2007). Food Security Indicators, Measurement, and the Impact of Trade Openness. Oxford University Press, WIDER Studies in Development Economics Series.

[11] Marble, A., Fritschel, H., (2014). 2013 Global Food Policy Report. Washington, D.C.: International Food Policy Research Institute (IFPRI).

[12] Muhammad Aswar Limi, Putu Arimbawa, Budiyanto, Nur Rahmah, Edi Dwi Cahyono (2018). The Roles of Local Institutions to Improve Farmer Access to Foods and Production Capacities. WSEAS Transactions on Business and Economics, 15, 488-494.

[13] Okunlola, F. A., Alatise, M. A., Ogunniyi, O. R., Adejumo, M. O., (2020). Financial Inclusion for Sustainable Economy: Empirical Evidence from Nigeria. WSEAS Transactions on Business and Economics, 17, 205-214.

[14] Runge, C., Senauer, B., Pardey, P.G., Rosegrant, M.W., (2003). Ending Hunger in Our Lifetime: Food Security and Globalization. DC, International Food Policy Research Institute, Washington.

[15] Taraba, P., (2019). Project Management Methods in Conditions of Business Companies in the Czech Republic. International Journal of Circuits, Systems and Signal Processing, 13, 46-52.

[16] Traub, L.N., Jayne, T.S., (2008). The effects of price deregulation on maize marketing margins in South Africa. Food Policy 33 (3), 224-236

[17] Upton, J.B., Cisse, J.D., Barrett, C.B., (2016). Food security as resilience: reconciling definition and measurement. Agric. Econ. 47 (1), 135-147

[18] World Bank, (2006). Repositioning nutrition as central to development: A strategy for large-scale action. Washington, D.C. 